\title{
Statolith microchemistry traces the environmental history of the boreoatlantic armhook squid Gonatus fabricii
}

\author{
Karsten Zumholz $^{1, *}$, Andreas Klügel ${ }^{2}$, Thor Hansteen ${ }^{1}$, Uwe Piatkowski ${ }^{1}$ \\ ${ }^{1}$ IFM-GEOMAR, Leibniz-Institut für Meereswissenschaften, Düsternbrooker Weg 20, 24105 Kiel, Germany \\ ${ }^{2}$ Universität Bremen, Fachbereich Geowissenschaften, Postfach 330440, 28334 Bremen, Germany
}

\begin{abstract}
Statoliths of the gonatid squid Gonatus fabricii from Disko Bay, West Greenland, were analysed by laser ablation inductively coupled plasma mass-spectrometry (LA-ICP-MS) to determine the concentrations and spatial distributions of 9 minor and trace elements ( $\mathrm{Sr}, \mathrm{Ba}, \mathrm{Mg}, \mathrm{U}, \mathrm{Zn}, \mathrm{Mn}, \mathrm{Y}$, $\mathrm{Zr}, \mathrm{Na}$ ). Element composition was assigned in situ to distinct statolith regions, corresponding to ontogenetic stages of an individual squid's life. Significant variations in concentrations of all measured elements except $\mathrm{Na}$ were found between different regions of the statolith. Variations in $\mathrm{Ba} / \mathrm{Ca}$ ratios suggest that juveniles inhabit surface waters, while larger specimens move to deeper waters. U/Ca and $\mathrm{Sr} / \mathrm{Ca}$ ratios increased towards the outer statolith region, suggesting migration of adult squid into colder waters. $\mathrm{Mg} / \mathrm{Ca}$ ratios decreased progressively from the core to the edge, most likely related to changes in protein concentrations in their microstructure during ontogenesis. This study is one of the first to apply LA-ICP-MS to cephalopod statoliths. Our results emphasise the strong potential of spatially resolved statolith analyses to gather information on life history, migrations and habitat use of cephalopods.
\end{abstract}

KEY WORDS: Statolith - Trace elements - Laser ablation ICP-MS - Cephalopods · Squid · Gonatus fabricii · Greenland

\section{INTRODUCTION}

The boreoatlantic armhook squid Gonatus fabricii (Lichtenstein, 1818) is the most abundant squid of the arctic and subarctic waters of the North Atlantic and is considered to have some commercial potential (Nesis 1965, Kristensen 1984, Zumholz \& Frandsen 2006). This species is frequently found in the stomachs of marine mammals and fishes (Lick \& Piatkowski 1998, Bjørke 2001) and is likely to play an important role in the ecosystem off West Greenland. G. fabricii is caught frequently as by-catch in the fishery of deep-water prawn Pandalus borealis, and locally it is kept and used as bait. The life cycle of the squid is characterised by well-defined ontogenetic vertical migrations as described by Arkhipkin \& Bjørke (1999). Hatching is pro- posed to take place at great depths (Arkhipkin \& Bjørke 1999). Its early life stages are found in large numbers in west Greenland epipelagic waters (Piatkowski \& Wieland 1993), while larger squids occur mainly in mesopelagic and bathypelagic layers (Kristensen 1984).

Trace element analysis of biomineralised tissues has become a frequently used method for determining environmental histories of many aquatic organisms. Although more commonly applied to fish otoliths (Campana 1999, 2005) and corals (e.g. Smith et al. 1979), many other marine organisms have calcified structures that may be similarly useful as natural tags (Zacherl et al. 2003a, Becker et al. 2005). Cephalopod statoliths share many structural similarities with fish otoliths (Clarke 1978). They are composed primarily of 
aragonite crystals associated with an organic matrix (Radtke 1983). Alternating layers of organic-rich and organic-poor material are deposited periodically. The 'one increment per day' hypothesis has been validated for several species (Jackson 1994, Bettencourt \& Guerra 2001), though not for G. fabricii. A comprehensive review of recent developments in statolith studies is given by Arkhipkin (2005).

Several studies have shown that statoliths contain a number of elements at minor and trace levels (e.g. Hurley et al. 1985, Durholtz et al. 1997, Lipinski et al. 1997, Yatsu et al. 1998, Ikeda et al. 2002a,b, Arkhipkin et al. 2004). Fundamental results on the biomineralisation process have been presented by Bettencourt \& Guerra (2000), but the exact principles of elemental uptake into statoliths are still unknown. Strontium has been shown to be essential for normal statolith development (Hanlon et al. 1989), while magnesium may also be a key factor in the calcification process within the statocyst (Morris 1991, Bettencourt \& Guerra 2000). Inspired by an inverse relationship between $\mathrm{Sr} / \mathrm{Ca}$ and temperature in scleractinian corals (Beck et al. 1992), several studies have attempted to use $\mathrm{Sr} / \mathrm{Ca}$ ratios in statoliths as a temperature proxy (e.g. Rodhouse et al. 1994, Ikeda et al. 2003). Arkhipkin et al. (2004) showed a good relationship between $\mathrm{Sr} / \mathrm{Ca}$ and ambient temperature in statoliths of the Patagonian longfin squid Loligo gahi collected in the field. However, no experimental studies have shown evidence that $\mathrm{Sr} / \mathrm{Ca}$ ratios in squid statoliths are temperature dependent.

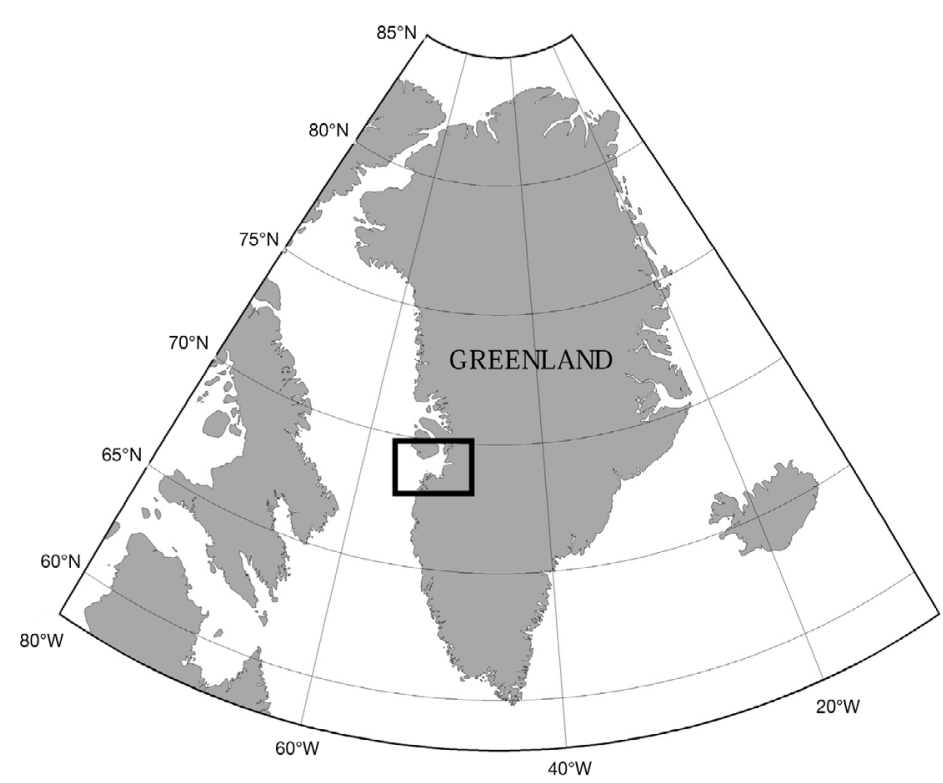

Fig. 1. Location of Disko Bay, West Greenland (box), where specimens of Gonatus fabricii were sampled from bottom trawl hauls in 2003. Map plotted with Ocean DataView (Schlitzer 2007)
The analysis of elemental signatures of whole dissolved statoliths ('elemental fingerprints') makes it possible to distinguish between populations and cohorts. This has been demonstrated convincingly for Loligo gahi (Arkhipkin et al. 2004). Furthermore, the same authors highlighted the potential of spatially resolved elemental analyses to determine stage-specific migrations and habitat use.

Based on optical increment analysis, Kristensen (1980) and Arkhipkin \& Bjørke (2000) defined 4 distinct growth zones (Z1, Z2, Z3, Z4) in the statoliths of Gonatus fabricii corresponding to different ontogenetic stages and thereby different habitat use, separated from each other by distinct checks. Z1 represents the embryo phase before hatching; Z2 and Z3 develop during the juvenile phase (up to $60 \mathrm{~mm}$ pen length). $\mathrm{Z} 4$ is formed during the subadult and adult periods.

No published information on the chemical composition of Gonatus fabricii statoliths has been available until now. In this study, transects on ground G. fabricii statoliths from the core to the edge were analysed, thereby determining the chemical composition of the different growth zones. The aim of this study was (1) to quantify the elemental composition and spatial distribution of elements within G. fabricii statoliths and (2) to find possible relations between statolith elemental composition and the habitat use and life history of individual squids.

\section{MATERIALS AND METHODS}

Sample collection. Specimens were sampled on board the RV 'Paamiut' as by-catch during a bottom trawl survey targeting deep-water prawn Pandalus borealis from July to August 2003 in Disko Bay, West Greenland (Fig. 1). Cephalopods were frozen on board immediately after capture and defrosted for further analyses at IFM-GEOMAR, Kiel. Sex was determined, and maturity stages (I-II, immature; III-IV, maturing; $\mathrm{V}$, mature) were estimated according to the appearance and relative size of the reproductive organs (Lipinski 1979). Pen length (PL) was measured to the nearest $1 \mathrm{~mm}$; total body wet mass (BM) was measured to the nearest $\mathrm{g}$. The sample used for this study consisted of 16 males (all specimens were assigned to maturity stage III) and 10 females (all specimens were assigned to maturity stage II). All specimens were caught within 3 hauls on the same day in the same area (stations: $68^{\circ} 57.51^{\prime} \mathrm{N}, \quad 52^{\circ} 07.35^{\prime} \mathrm{W}_{;} \quad 69^{\circ} 09.46^{\prime} \mathrm{N}, \quad 53^{\circ} 20.15^{\prime} \mathrm{W}$; $\left.69^{\circ} 09.46^{\prime} \mathrm{N}, 53^{\circ} 02.85^{\prime} \mathrm{W}\right)$. The statoliths were dissected from the cephalic cartilage, washed in distilled water, stored in Eppendorf caps and kept dry.

Statolith processing and reading. In total, 26 statoliths were prepared and analysed. One statolith from 


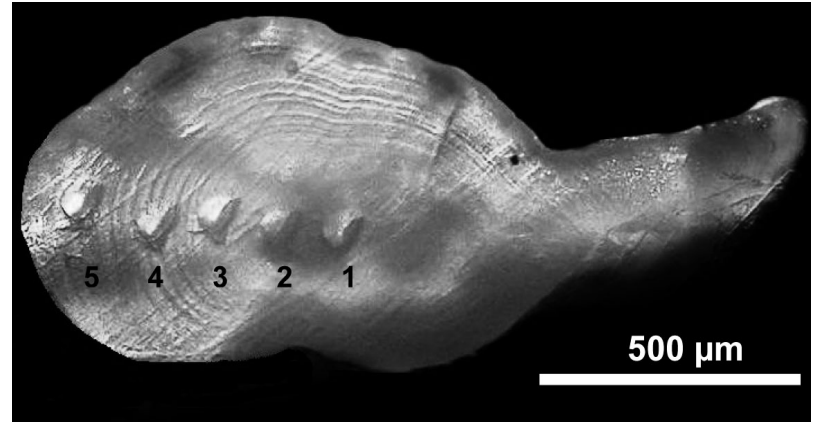

Fig. 2. Gonatus fabricii. Ground statolith showing the location of analytical points as laser ablation craters. Points are numbered from the core to the edge

each pair was attached concave side up onto a microscopic glass slide with thermoplastic resin (Buehler) and was ground on one side with wet waterproof lapping film $\left(3 \mathrm{M}^{\circledR}{ }_{;} 30 \mu \mathrm{m}, 15 \mu \mathrm{m}, 3 \mu \mathrm{m}\right)$ until the ground surface extended to the edge (i.e. the most extended point) of the dorsal dome, and the core (corresponding to the embryonic phase) could be seen just beneath the ground surface. Ground statoliths were finally polished with Buehler micropolish II $(0.3 \mu \mathrm{m}$ and $0.05 \mu \mathrm{m})$ and observed under a Leitz Laborlux $\mathrm{K}$ microscope (250× magnification) to locate the growth zones as defined by Kristensen (1980).

Elemental analyses. The polished statoliths used for element analysis were triple-rinsed in MilliQ water (>18 M $\Omega \mathrm{cm}$ ). Five analytical points were located along a transect from the core to the edge of each statolith (Fig. 2). The first point was placed in the core, i.e. the region laid down before hatching, which was designated zone Z1 according to Kristensen (1980). Points 2 and 3 were placed in the post-nuclear zones Z2 and Z3, while Points 4 and 5 both were located in Z4, representing the subadult and adult phase in a squid's life (Kristensen 1980, Arkhipkin \& Bjørke 1999). In some cases, especially at the core, the measured element ratios changed after some time when the laser drilled into a different zone. Here only the first part of the time series was integrated for data quantification to obtain a true 2-dimensional profile along the sample surface.

The chemical analyses of statoliths were carried out at the Institute of Geosciences, University of Bremen, using a $266 \mathrm{~nm}$ frequency-quadrupled Nd:YAG laser (Finnigan UV LaserProbe) coupled to a ThermoFinnigan Element2 ICP-MS. Helium was used as sample gas in the ablation cell $\left(0.41 \mathrm{~min}^{-1}\right)$ and argon was subsequently added $\left(0.81 \mathrm{~min}^{-1}\right)$ to the gas flow. Ablation parameters included a laser energy of 2 to $2.5 \mathrm{~mJ}$ (Qswitched mode) and a pulse rate of $5 \mathrm{~Hz}$ resulting in crater sizes of 60 to $80 \mu \mathrm{m}$. Eleven isotopes were recorded during $90 \mathrm{~s}$ with 5 samples at each peak's flat top and a total dwell time of $50 \mathrm{~ms}$ per isotope. Owing to the lack of matrix-matched standards, the glass reference materials NIST610 (for ${ }^{23} \mathrm{Na},{ }^{43} \mathrm{Ca},{ }^{88} \mathrm{Sr}$ ) and NIST612 (for ${ }^{23} \mathrm{Na},{ }^{25} \mathrm{Mg},{ }^{43} \mathrm{Ca},{ }^{55} \mathrm{Mn},{ }^{64} \mathrm{Zn},{ }^{89} \mathrm{Y},{ }^{90} \mathrm{Zr}$, $\left.{ }^{93} \mathrm{Nb},{ }^{138} \mathrm{Ba}^{2}{ }^{238} \mathrm{U}\right)$ were used for external calibration taking the accepted concentrations of Pearce et al. (1997). Both standards were analysed and a new calibration line established after every 5 to 11 data points (standard bracketing) to compensate for any instrumental drift. GeoPro software was used to define a blank of 8-20 s duration and a stable signal period of 15-50 s duration following a pre-ablation period of 5-13 s for each measured point. For quantification, the blank was subtracted and Ca was used as internal standard element with an assumed stoichiometric concentration of $40 \mathrm{wt} \%$. Single-point calibration was preferred over 2-point calibration, because the 2 differently coloured NIST standards show distinct ablation behaviour and element fractionation at a laser wavelength of $266 \mathrm{~nm}$ (Guillong et al. 2003).

The external analytical precision was determined through replicate analyses of the homogeneous standard reference materials NIST612 and GOR128G (basaltic glass with low concentrations of some trace elements; Jochum et al. 2000). The data indicate a precision of better than $3 \%$ for concentrations above $1 \mathrm{\mu g} \mathrm{g}^{-1}$ (Na, Sr, Mg, Ba, Mn and $\mathrm{Zn}$ ) and better than $13 \%$ for concentrations between 0.01 and $1 \mu^{-1} \mathrm{~g}^{-1}$ (Y, $\mathrm{Zr}$ and $\mathrm{Nb}$ ). Assessing the accuracy is difficult due to the lack of a homogeneous matrix-matched reference material. Analyses of GOR128G yielded a good to moderate accuracy (Table 1a), which was limited by concentrations far outside the calibration range for some elements $(\mathrm{Na}, \mathrm{Mn})$ as well as by different element fractionation of the translucent calibration standard and the opaque basaltic glass (Guillong et al. 2003).

We also analysed a powdered Arctica islandica bivalve shell both by laser ablation inductively coupled plasma mass-spectrometry (LA-ICP-MS), using the same analytical method and parameters as for statolith analyses, and by solution ICP-MS calibrated with concentration-matched pure element standards. Even though the measured concentrations covered a wide range of $10^{-3}$ to $10^{3} \mu \mathrm{g} \mathrm{g}^{-1}$, the laser ablation data showed excellent to moderate accuracy (Table $1 \mathrm{~b}$ ).

Statistical analysis. Two-way analysis of variance (ANOVA) was used to test for significant differences in element/Ca ratios among specimens and between the statolith growth zones (location of measurements). Specimens were treated as random variables, locations of measurements were treated as categorical variables and element/Ca ratios were treated as dependent variables in the analyses. 
Table 1. (a) Accuracy and reproducibility (as expressed by the relative standard deviation, RSD) of 10 consecutive LA-ICPMS analyses of basaltic glass reference material GOR128G (Jochum et al. 2000) using the same analytical method and parameters as for statolith analyses. (b) Averaged results of 10 replicate LA-ICP-MS analyses of a pressed pellet made from a powdered Arctica islandica bivalve shell, which has trace element concentrations similar to statoliths, as compared to 2 analyses of the same powder by solution ICP-MS calibrated at appropriate concentrations with pure element standards. Despite a wide range of measured concentrations, there is good agreement between both methods for most elements

\begin{tabular}{|c|c|c|c|}
\hline $\begin{array}{l}\text { (a) } \\
\text { Element }\end{array}$ & $\begin{array}{l}\text { Average } \\
\left(\mu g^{-1}\right)\end{array}$ & $\begin{array}{l}\text { Ref. value } \\
\left(\mu \mathrm{g} \mathrm{g}^{-1}\right)\end{array}$ & $\begin{array}{l}\text { RSD } \\
(\%)\end{array}$ \\
\hline Sodium & 3906 & 4130 & 1.5 \\
\hline Strontium & 28.17 & 31 & 1.4 \\
\hline Barium & 0.954 & 1.09 & 1.7 \\
\hline Zinc & 84.52 & 74 & 3.6 \\
\hline Manganese & 1247 & 1390 & 1.1 \\
\hline Yttrium & 9.91 & 11.3 & 1.4 \\
\hline Zirconium & 8.08 & 10.2 & 1.4 \\
\hline Niobium & 0.085 & 0.11 & 4.5 \\
\hline Uranium & 0.011 & 0.013 & 13.0 \\
\hline \multicolumn{4}{|l|}{ (b) } \\
\hline Element & $\begin{array}{l}\text { LA-ICP-MS } \\
\quad\left(\mu \mathrm{g} \mathrm{g}^{-1}\right)\end{array}$ & $\begin{array}{l}\text { Solution } 1 \\
\left(\mu \mathrm{g} \mathrm{g}^{-1}\right)\end{array}$ & $\begin{array}{c}\text { Solution } 2 \\
\left(\mu \mathrm{g} \mathrm{g}^{-1}\right)\end{array}$ \\
\hline Strontium & 1049 & 1186 & 1195 \\
\hline Magnesium & 126.1 & 109 & 102 \\
\hline Barium & 11.06 & 11.89 & 11.83 \\
\hline Zinc & 0.847 & 1.38 & 1.09 \\
\hline Yttrium & 0.023 & 0.020 & 0.020 \\
\hline Zirconium & 0.046 & 0.017 & 0.027 \\
\hline Niobium & 0.007 & 0.0020 & 0.0019 \\
\hline Uranium & 0.010 & 0.0109 & 0.0107 \\
\hline
\end{tabular}

Table 2. Gonatus fabricii. Ranges of concentrations and element/Ca ratios in statoliths measured by LA-ICP-MS. In the right column, data from Arkhipkin et al. (2004) for Loligo gahi statoliths, measured by solution-based ICP-MS, are listed for comparison

\begin{tabular}{|c|c|c|c|}
\hline \multirow[t]{2}{*}{ Element } & \multirow[t]{2}{*}{$\begin{array}{l}\text { Concentration range } \\
\qquad\left(\mu \mathrm{g} \mathrm{g}^{-1}\right)\end{array}$} & \multicolumn{2}{|c|}{ 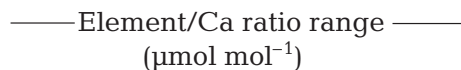 } \\
\hline & & Gonatus fabricii & Loligo gahi \\
\hline Sodium & 3200 to 5050 & 15000 to 22000 & \\
\hline Strontium & 5500 to 7100 & 6300 to 8100 & $\sim 8000$ to 8500 \\
\hline Magnesium & 25 to 140 & 110 to 590 & $\sim 70$ to 350 \\
\hline Barium & 7.8 to 11.3 & 5.7 to 8.2 & $\sim 3$ to 8 \\
\hline Zinc & 0.6 to 2.9 & 0.9 to 4.5 & \\
\hline Manganese & 1.8 to 3.7 & 3.2 to 6.8 & $\sim 1$ to 3 \\
\hline Yttrium & 0.02 to 0.14 & 0.056 to 0.081 & \\
\hline Zirconium & 0.01 to 0.026 & 0.012 to 0.029 & \\
\hline Uranium & 0.005 to 0.022 & 0.002 to 0.009 & \\
\hline Lead & 0.013 to 0.076 & 0.006 to 0.037 & $\sim 0.002$ to 0.030 \\
\hline
\end{tabular}

Table 3. Gonatus fabricii. Analysis of variance (ANOVA) table summarising the effect of statolith measurement location on element/Ca ratios. df: degrees of freedom; SS: sum of squares; MS: mean squares

\begin{tabular}{|lcrrrr|}
\hline Element & df & \multicolumn{1}{c}{ SS } & MS & \multicolumn{1}{c|}{$F$} & $\mathrm{p}$ \\
\hline Strontium & 4 & 8.19 & 2.05 & 16.65 & 0.0001 \\
Barium & 4 & 4.17 & 1.04 & 4.90 & 0.0009 \\
Magnesium & 4 & 173540 & 43385 & 2.88 & 0.026 \\
Sodium & 4 & 2.51 & 0.63 & 0.20 & 0.936 \\
Manganese & 4 & 41.98 & 10.50 & 15.16 & 0.0001 \\
Zinc & 4 & 27.24 & 6.8 & 3.54 & 0.009 \\
Yttrium & 4 & 919.0 & 229.70 & 3.79 & 0.0059 \\
Zirconium & 4 & 267.62 & 66.90 & 5.99 & 0.0002 \\
Uranium & 4 & 124.21 & 31.10 & 32.23 & 0.0001 \\
\hline
\end{tabular}

\section{RESULTS}

The pen length of analysed squid ranged from 177 to $310 \mathrm{~mm}$, corresponding to a weight range of 84 to $470 \mathrm{~g}$. Total statolith length as defined by Arkhipkin \& Bjørke (2000) ranged from 1.24 to $1.48 \mathrm{~mm}$. Nine minor and trace elements ( $\mathrm{Sr}, \mathrm{Ba}, \mathrm{Mg}, \mathrm{Mn}, \mathrm{U}, \mathrm{Zr}, \mathrm{Y}, \mathrm{Zn}$ and $\mathrm{Na}$ ) were analysed in the statoliths by LA-ICP-MS. The ranges of element/Ca ratios are given in Table 2 . The lateral resolution achieved by laser ablation in this study, approximately $70 \mu \mathrm{m}$, was adequate to sample single ontogenetic stages on the polished statolith surface.

The 2-way ANOVA test found no significant effect of specimens on the statolith elemental composition $(\mathrm{p}>$ $0.5)$ and no interaction between specimens and location of measurements. The location of measurements, however, showed significant effects for all analysed elements except sodium (Table 3). Post-hoc Tukey multiple comparisons revealed significant differences in the elemental composition between distinct regions in the statoliths (Fig. 3) as described below.

$\mathrm{Sr} / \mathrm{Ca}$ ratios were highest in the core region, decreasing towards the middle and slightly increasing towards the edge. Core values were significantly higher than all other points ( $p<0.0003$ ). A significant difference was also found between Points 3 and 5 $(\mathrm{p}<0.03)$.

$\mathrm{Ba} / \mathrm{Ca}$ ratios showed considerable variation within the post-hatch Zones Z2 to Z4. Concentrations in the outer regions (Points 4 and 5) were significantly higher than Points 2 and 3 $(p<0.007)$. However, variations between the core and the rest were not significant. 

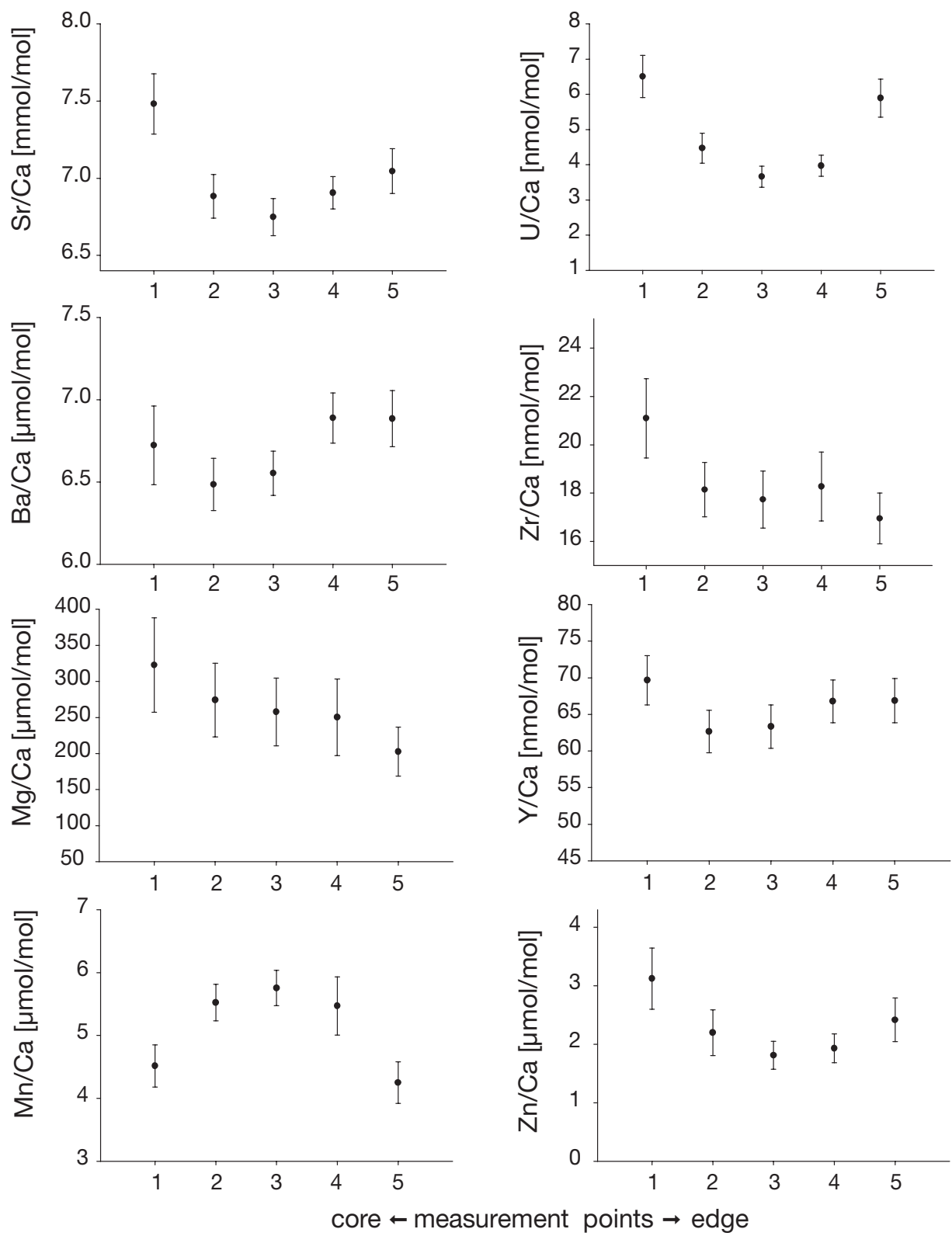

Fig. 3. Gonatus fabricii. Element/Ca ratios measured by LA-ICP-MS in different regions of statoliths from the core to the edge. Point numbers refer to numbers given in Fig. 2. Point 1 = Growth Zone Z1; Point $2=$ Growth Zone Z2; Point $3=$ Growth Zone Z3; Points 4 and 5 = Growth Zone Z4. Each point represents the mean of measurements in 26 statoliths, error bars indicate $95 \%$ confidence intervals

$\mathrm{Mg} / \mathrm{Ca}$ ratios were generally high in the core, with the lowest values in the outermost region. Significant differences were observed only between Points 1 and 5 $(\mathrm{p}=0.01)$.

$\mathrm{Mn} / \mathrm{Ca}$ ratios showed a dome-shaped pattern along the transect, with low values in the core and the outer region and the highest values in the middle. This pattern was negatively related to the Sr distribution. Values for Points 1 and 5 were significantly different from Points 2,3 and $4(\mathrm{p}<0.003)$.
U/Ca ratios followed a U-shaped pattern along the transect, with high values in the core and the outer region and lower values in the middle. This pattern was very similar to the $\mathrm{Sr} / \mathrm{Ca}$ distribution. Values for Points 1 and 5 were significantly different from Points 2,3 and $4(\mathrm{p}<0.0002)$.

$\mathrm{Zr} / \mathrm{Ca}$ ratios showed the highest values in the core, with lower values in the outer regions. Core values were significantly higher than all other points $(p<$ 0.002). 
Y/Ca ratios in the core were significantly higher than in Growth Zones 2 and 3 ( $p<0.008)$, but did not differ from Growth Zone 4.

$\mathrm{Zn} / \mathrm{Ca}$ ratios showed a similar pattern to $\mathrm{Sr} / \mathrm{Ca}$. The highest values were in the core region, decreasing towards the middle and slightly increasing towards the edge. Core values were significantly higher than Points 3 and $4(\mathrm{p}<0.03)$.

\section{DISCUSSION}

\section{Pre-hatch zone}

Analyses revealed that the elemental composition differed considerably between the core region (representing time before hatching) and the outer parts. Concentrations of 7 elements were significantly different between the pre-hatch zone and the post-hatch zones. This change could be due to the difference in the elemental compositions within the egg-capsules compared to seawater. As Yatsu et al. (1998) pointed out, $\mathrm{Sr} / \mathrm{Ca}$ ratios in cephalopod statoliths are probably affected in a different way during the embryonic period compared to other ontogenetic stages, because embryos have no direct contact with ambient water but rely on their yolk. Since yolk composition may well be influenced by genetic factors, the elemental signature of the statolith core could be representative for separate populations. In cuttlefish eggs, the capsule was shown to protect embryos against trace metals like $\mathrm{Zn}$ and Cd (Bustamante et al. 2002). However, at least for $\mathrm{Zn}$, this protection cannot be supported by our results. Further, there is also evidence that environmental conditions, specifically temperature, can affect $\mathrm{Sr}$ contents in statoliths of encapsulated marine neogastropod larvae (Zacherl et al. 2003b). In this context, it would be desirable to analyse the elemental composition of the liquid inside the eggs and the yolk to learn about relations between statolith composition and these factors.

\section{Strontium}

Gonatus fabricii statoliths, similar to other cephalopods, corals and sclero-sponges, contain more $\mathrm{Sr}$ ( $\mathrm{Sr} / \mathrm{Ca}$ ratio $~ 6.3-8.1 \mathrm{mmol} \mathrm{mol}^{-1}$ ) than fish otoliths ( 2-2.5 mmol mol${ }^{-1}$, Campana 1999) or bivalve shells ( 0.8-1.6 mmol mol${ }^{-1}$, e.g. Vander Putten et al. 2000). Among cephalopods, statolith $\mathrm{Sr} / \mathrm{Ca}$ ratios in $G$. fabricii are relatively low compared with those of the oceanic ommastrephid squid Todarodes pacificus (8.5-10 mmol mol ${ }^{-1}$; Ikeda et al. 2003) and a species of benthic octopus, Octopus dofleini (10.6-14.3 mmol $\mathrm{mol}^{-1}$; Ikeda et al. 1999), but quite high compared with the common cuttlefish Sepia officinalis (3.5-6.5 mmol $\mathrm{mol}^{-1}$; Zumholz et al. 2006). However, statolith $\mathrm{Sr} / \mathrm{Ca}$ data in the current study are very similar to those of loliginid squid species (Ikeda et al. 1997, Biemann \& Piatkowski 2001, Arkhipkin et al. 2004).

Applying the generally suggested negative correlation between $\mathrm{Sr} / \mathrm{Ca}$ and temperature (Arkhipkin et al. 2004), the higher $\mathrm{Sr} / \mathrm{Ca}$ in the outer region compared to Growth Zone 3 may indicate a migration into colder waters. This scenario is supported by $\mathrm{Ba} / \mathrm{Ca}$ and $\mathrm{U} / \mathrm{Ca}$ patterns and complies with the proposed life-cycle of Gonatus fabricii (Arkhipkin \& Bjørke 1999). However, no data for $\mathrm{Sr} / \mathrm{Ca}$ incorporation into cephalopod statoliths from laboratory experiments exist for calibration.

The considerably higher core values may not be due to ambient water but rather to the yolk and the withinegg fluid surrounding the embryo during pre-hatch development. For example, Sr/Ca ratios in the primordium (the initial complex structure within fish otolith nuclei) of salmonids are considered to be directly influenced by the Sr content of the individual's yolk (Kalish 1990).

\section{Barium}

$\mathrm{Ba} / \mathrm{Ca}$ ratios from the current study are in the same range as the ratios for Loligo gahi (Arkhipkin et al. 2004). Ba is known to show nutrient-like distributions, i.e. very low concentrations in surface waters and considerably higher values in deeper waters (Chan et al. 1977). In corals, Ba is therefore used as an indicator for upwelling events (Lea et al. 1989). Experimental data indicate a positive correlation of $\mathrm{Ba} / \mathrm{Ca}$ in gastropod larvae protoconchs (Zacherl et al. 2003b) and fish otoliths (Bath et al. 2000, Elsdon \& Gillanders 2003, Bath-Martin et al. 2004) with $\mathrm{Ba} / \mathrm{Ca}$ in the seawater. The $\mathrm{Ba} / \mathrm{Ca}$ distribution found in our study corresponds to the previously stated ontogenetic migrations from surface waters during the juvenile stage to mesobathy-pelagic waters in the subadult and adult stages in Gonatus fabricii (Kristensen, 1984). Therefore, $\mathrm{Ba} / \mathrm{Ca}$ in statoliths appears to be a very useful indicator for vertical movements of cephalopods as suggested by Arkhipkin et al. (2004) for L. gahi. However, seasonal or persistent upwelling conditions can complicate the interpretation.

\section{Magnesium}

Magnesium has been assumed to be important for biomineralisation in squid statoliths (Morris 1991). Statolith core regions are characterised by relatively high 
$\mathrm{Mg} / \mathrm{Ca}$ ratios that decline progressively towards the edge. This trend probably reflects the growth rate, which is rather high in Growth Zones 2 and 3 and decreases considerably in Growth Zone 4 (Kristensen 1980, Arkhipkin \& Bjørke 2000). Bettencourt \& Guerra (2000) showed that $\mathrm{Mg}^{2+}$ concentration in the statocyst endolymph is associated with the deposition of organic components into the statolith. Since the proportion of organic components in statoliths decreases with the size of the squid (Bettencourt \& Guerra 2000), concentrations of $\mathrm{Mg}$ would be expected to decrease correspondingly, which is in accordance with the data presented in this study.

$\mathrm{Mg} / \mathrm{Ca}$ ratios are positively correlated with temperature in coral skeletons (Mitsuguchi et al. 1996), but a corresponding relation has not been shown for cephalopods or fish. A relation of statolith $\mathrm{Mg} / \mathrm{Ca}$ to $\mathrm{Mg} / \mathrm{Ca}$ ratios or $\mathrm{Mg}$ concentrations in the seawater seems even more unlikely because this element is physiologically highly regulated and nearly uniformly distributed in ocean waters.

The Mg/Ca values in the core were slightly higher than the values reported for Loligo gahi statoliths (Arkhipkin et al. 2004), which is not surprising since these authors obtained the elemental composition integrated over the whole statolith, pooling high core values with lower outer values. However, by comparing statoliths from juveniles and adults, they found a similar ontogenetic pattern with declining $\mathrm{Mg} / \mathrm{Ca}$ values in bigger specimens.

\section{Manganese}

$\mathrm{Mn} / \mathrm{Ca}$ values in this study were similar to values in Loligo gahi statoliths ( 1-3 $\mu \mathrm{mol} \mathrm{mol}^{-1}$; Arkhipkin et al. 2004) determined by ICP-MS. However, the values of both data sets are substantially lower than in Todarodes

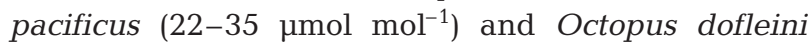
(22-40 $\mathrm{mmol} \mathrm{mol}^{-1}$ ) determined by proton-induced Xray emission (Ikeda et al. 1995, 1999). The distribution of $\mathrm{Mn}$ in the world's oceans, however, is rather uniform (Donat \& Bruland 1995). Therefore, as stated by Arkhipkin et al. (2004), these differences in statolith composition are probably due to taxon-specific uptake mechanisms or to instrumental artefacts rather than to environmental influences. In statoliths of $L$. gahi (Arhkhipkin et al. 2004) a decrease of Mn/Ca with increasing squid size was observed. This is in accordance with the current study, considering that Arkhipkin et al. (2004) analysed the whole statolith of specimens $>7.5 \mathrm{~cm}$ mantle length. These statoliths already contain zones Z1 to Z3 as constant factors; therefore, a Mn/Ca ratio decreasing from $\mathrm{Z} 3$ towards the edge results in a decrease of $\mathrm{Mn} / \mathrm{Ca}$ with increasing squid size.

\section{Uranium}

Uranium has never before been determined in statoliths. Spatial and vertical distributions of dissolved $\mathrm{U}$ in the world's oceans have been reported to be rather uniform, at $3.4 \pm 0.3 \mathrm{ng} \mathrm{g}^{-1}$ (Hossain \& Ohde 2002). Reef-building corals incorporate $U$ in the form of uranyl ions $\left(\mathrm{UO}_{2}{ }^{2+}\right)$ as impurities by replacing $\mathrm{Ca}^{2+}$ (Ohde et al. 2003) in a concentration range of 2 to $3.5 \mathrm{\mu g} \mathrm{g}^{-1}$ (Shen \& Dunbar 1995). U concentrations in statoliths from this study were 2 orders of magnitude lower, but they showed considerable spatial variation.

Shen \& Dunbar (1995) proposed a possible U/Ca temperature dependence of +3 to $4 \%$ per $1^{\circ} \mathrm{C}$ cooling for coral aragonite. Moreover, the same authors identified a probably positive salinity influence on coral U/Ca, which suggests that U uptake depends on the total $U$ concentration in seawater and not on the U/Ca ratio. Applying these relations to results for Gonatus fabricii statoliths, low U values in Z2, Z3 and early $\mathrm{Z} 4$ (juvenile and subadult phases) correspond to the warm, low-saline surface water in Disko Bay. The higher U values in Z1 (time before hatching) and late Z4 (adult phase) indicate habitation in deeper, more saline waters. A significant correlation $(\mathrm{r}=0.56, \mathrm{p}<0.01)$ was found between U/Ca and $\mathrm{Sr} / \mathrm{Ca}$, which agrees with previous studies on corals (Min et al. 1995). The combination of $\mathrm{Sr}$ and $\mathrm{U}$, which are incorporated into corals at different ratios with respect to temperature, is used regularly for sea surface temperature reconstruction (Correge et al. 2001). Experiments on these relations have yet to be performed on cephalopods, but the data presented here suggest a strong potential of U/Ca in statoliths as a temperature proxy for future studies. Our results further showed significant variations within Z4, a region that is optically homogenous. This outlines the ability of spatially resolved chemical analyses to provide far more information than optical analyses alone.

\section{Other elements}

Zinc, yttrium and zirconium concentrations in the statoliths did not vary significantly along the posthatch ontogenetic stages. However, core values for all of these elements were significantly higher than in the outer regions. Zn has previously been measured in statoliths (Ikeda et al. 1996), but convincing relations to environmental factors have not been proposed yet. Y and $\mathrm{Zr}$ have never before been analysed in cephalopod statoliths, but spatial variations found in this study suggest some potential for future use as environmental 
proxies. These elements should be further investigated in biogenic aragonite to evaluate their incorporation process.

Lead could not reliably be measured in Gonatus fabricii statoliths due to low concentrations and apparent surface contamination in some samples. Preliminary data showed $\mathrm{Pb} / \mathrm{Ca}$ of 6.3 to $37 \mathrm{nmol} \mathrm{mol}^{-1}$ for 2 specimens, which is comparable to $\mathrm{Pb} / \mathrm{Ca}$ ratios found in Loligo gahi statoliths with solution-based ICP-MS $\left(\sim 2-30 \mathrm{nmol} \mathrm{mol}^{-1}\right.$; Arkhipkin et al. 2004).

\section{Suitability of laser ablation ICP-MS}

LA-ICP-MS as used in this study proved to be a wellsuited technique for the micro-analysis of trace elements in statoliths over a range of concentrations from $<0.01 \mu \mathrm{g} \mathrm{g}^{-1}$ to several thousand $\mu \mathrm{g} \mathrm{g}^{-1}$. A main factor limiting the accuracy of the data is the lack of suitable matrix-matched homogeneous calibration standards. The NIST610 glass often used for calibration differs strongly from the analyte by both colour and bulk composition, which results in different element fractionation during ablation (Guillong et al. 2003) and hence in limited accuracy for some elements. Additional errors arise by measured concentrations being far outside the calibration range, since NIST610 has much higher Y, $\mathrm{Zr}, \mathrm{Nb}$ and $\mathrm{U}$ and much lower Sr contents than the samples. Despite these limitations, the good analytical precision combined with the spatial resolution enabled significant zonations to be recognised.

We chose a spatial resolution of about $70 \mu \mathrm{m}$ to be able to differentiate between the squid's main ontogenetic stages. A higher spatial resolution down to about $10 \mu \mathrm{m}$ is possible but would result in poorer signal quality, significantly lower intensities and hence in higher detection limits, making detection of trace elements such as U, Y and $\mathrm{Zr}$ impossible. Increased laser energy, in turn, would increase the deepening rate of the ablation crater and reduce the spatial resolution especially at the statolith core. Therefore, the analytical setup used here represented a reasonable compromise between spatial resolution and detection limits. In order to obtain true 2-dimensional profiles, the laser beam should ideally ablate along a raster in the core and along lines parallel to the growth lines. However, this was not possible with the laser system used in this study.

In comparison to solution-based ICP-MS analyses of Loligo gahi statoliths (Arkhipkin et al. 2004), we obtained the same magnitudes of concentrations by LA-ICP-MS (Table 2). The main advantage of laser ablation is the high spatial resolution, which counterbalances the slightly poorer accuracy and detection limits as compared to solution ICP-MS analyses. LA-
ICP-MS is therefore suitable to assign element composition in situ to distinct statolith regions, corresponding to ontogenetic stages of individual squids.

Acknowledgements. We are grateful to K. Wieland and the crew of RV 'Paamiut' for collecting the cephalopods, and R. P. Frandsen for assistance with dissecting specimens. H. Anders helped with solution ICP-MS analyses, and V. Epplé provided the Arctica islandica sample. G. Kraus and D. Schnack provided valuable comments, which considerably improved this manuscript. J. Schmidt is acknowledged for assistance with Fig. 1. This study was supported by grants from the Deutsche Forschungsgemeinschaft (Pi 203/11-1, Pi 203/11-2 and Ha 2100/9-1).

\section{LITERATURE CITED}

Arkhipkin AI (2005) Statoliths as 'black boxes' (life recorders) in squid. Mar Freshw Res 56:573-583

Arkhipkin AI, Bjørke H (1999) Ontogenetic changes in morphometric and reproductive indices of the squid Gonatus fabricii (Oegopsida, Gonatidae) in the Norwegian Sea. Polar Biol 22:357-365

Arkhipkin AI, Bjørke H (2000) Statolith shape and microstructure as indicators of ontogenetic shifts in the squid Gonatus fabricii (Oegopsina, Gonatidae) from the Norwegian Sea. Polar Biol 23:1-10

Arkhipkin AI, Campana SE, FitzGerald J, Thorrold SR (2004) Spatial and temporal variation in elemental signatures of statoliths from the Patagonian longfin squid (Loligo gahi). Can J Fish Aquat Sci 61:1212-1224

Bath GE, Thorrold SR, Jones CM, Campana SE, McLaren JW, Lam JWH (2000) Sr and Ba uptake in aragonitic otoliths of marine fish. Geochim Cosmochim Acta 64:1705-1714

Bath-Martin G, Thorrold SR, Jones CM (2004) Temperature and salinity effects on strontium incorporation in otoliths of larval spot (Leiostomus xanthurus). Can J Fish Aquat Sci 61:34-42

Beck JW, Edwards RL, Ito E, Taylor FW, Recy J, Rougerie F, Joannot P, Henin C (1992) Sea-surface temperature from coral skeletal strontium/calcium ratios. Science 257: 644-647

Becker BJ, Fodrie FJ, McMillan PA, Levin LA (2005) Spatial and temporal variation in trace elemental fingerprints of mytilid mussel shells: a precursor to invertebrate larval tracking. Limnol Oceanogr 50:48-61

Bettencourt V, Guerra A (2000) Growth increments and biomineralization process in cephalopod statoliths. J Exp Mar Biol Ecol 248:191-205

Bettencourt V, Guerra A (2001) Age studies based on daily growth increments in statoliths and growth lamellae in cuttlebone of cultured Sepia officinalis. Mar Biol 139: $327-334$

Biemann MD, Piatkowski U (2001) Amounts and composition of trace elements in the statoliths of loliginid squids: Reflection of environmental conditions? ICES CM 2001/ K:05 (Abstract)

Bjørke H (2001) Predators of the squid Gonatus fabricii (Lichtenstein) in the Norwegian Sea. Fish Res 52:113-120

Bustamante P, Teyssié JL, Fowler SW, Cotret O, Danis B, Miramand P, Warnau M (2002) Biokinetics of zinc and cadmium accumulation and depuration at different stages in the life cycle of the cuttlefish Sepia officinalis. Mar Ecol Prog Ser 231:167-177 
Campana SE (1999) Chemistry and composition of fish otoliths: pathways, mechanisms and applications. Mar Ecol Prog Ser 188:263-297

Campana SE (2005) Otolith science entering the 21st century. Mar Freshw Res 56:485-495

Chan LH, Drummond D, Edmund JM, Grant B (1977) On the barium data from the Atlantic GEOSECS expedition. Deep Sea Res 24:613-649

Clarke MR (1978) The cephalopod statolith - an introduction to its form. J Mar Biol Assoc UK 58:701-712

Correge T, Quinn T, Delcroix T, Le Cornec F, Recy J, Cabioch G (2001) Little ice age sea surface temperature variability in the southwest tropical Pacific. Geophys Res Lett 28: $3477-3480$

Donat JR, Bruland KW (1995) Trace elements in the oceans. In: Salbu B, Steinnes E (eds) Trace elements in natural waters. CRC Press, Boca Raton, FL, p 247-281

Durholtz MD, Lipinski MR, Przybylowicz WJ, Mesjasz-Przybylowicz J (1997) Nuclear microprobe mapping of statoliths of Chokka Squid Loligo vulgaris reynaudii d'Orbigny, 1845. Biol Bull 193:125-140

Elsdon TS, Gillanders BM (2003) Relationship between water and otolith elemental concentrations in juvenile black bream Acanthopagrus butcheri. Mar Ecol Prog Ser 260: 263-272

Guillong M, Horn I, Günther D (2003) A comparison of 266 $\mathrm{nm}, 213 \mathrm{~nm}$ and $193 \mathrm{~nm}$ produced from a single solid state Nd:YAG laser for laser ablation ICP-MS. J Anal Atom Spectr 18:1224-1230

Hanlon RT, Bidwell JP, Tai R (1989) Strontium is required for statolith development and thus normal swimming behaviour of hatchling cephalopods. J Exp Biol 141(1):187-195

Hossain MMM, Ohde S (2002). Uranium in pore water from coastal sediments determined by chemical activation analysis. J Radioanal Nucl Chem 251:333-336

Hurley GV, Odense P, O'Dor RK, Dawe EG (1985). Strontium labelling for verifying daily growth increments in the statoliths of the short-finned squid (Illex illecebrosus). Can J Fish Aquat Sci 42:380-383

Ikeda Y, Arai N, Sakamoto W, Murayama T, Maeda K, Yoshida K (1995) Preliminary report on the PIXE analysis of the squid statoliths. Int J PIXE 5:159-162

Ikeda Y, Arai N, Sakamoto W, Kidokoro H, Yoshida K (1996) Relationship between statoliths and environmental variables in cephalopods. Int J PIXE 6:339-345

Ikeda Y, Arai N, Sakamoto W, Kidokoro H, Yatsu A, Nateewathana A, Yoshida K (1997) Comparison on trace elements in squid statoliths of different species' origin as available key for taxonomic and phylogenetic study. Int $\mathrm{J}$ PIXE 7:141-146

Ikeda Y, Arai N, Sakamoto W, Mitsuhashi M, Yoshida K (1999) Preliminary report on PIXE analysis for trace elements of Octopus dofleini statoliths. Fish Sci 65:161-162

Ikeda Y, Okazaki J, Sakurai Y, Sakamoto W (2002a) Periodic variation in $\mathrm{Sr} / \mathrm{Ca}$ ratios in statoliths of the Japanese Common Squid Todarodes pacificus Steenstrup, 1880 (Cephalopoda: Ommastrephidae) maintained under constant water temperature. J Exp Mar Biol Ecol 273:161-170

Ikeda Y, Yatsu A, Arai N, Sakamoto W (2002b) Concentration of statolith trace elements in the jumbo flying squid during El Niño and non-El Niño years in the eastern Pacific. J Mar Biol Assoc UK 82:863-866

Ikeda Y, Arai N, Kidokoro H, Sakamoto W (2003) Strontium: calcium ratios in statoliths of Japanese common squid Todarodes pacificus (Cephalopoda: Ommastrephidae) as indicators of migratory behaviour. Mar Ecol Progr Ser 251: $169-179$
Jackson GD (1994) Application and future potential of statolith increment analysis in squid and sepioids. Can J Fish Aquat Sci 51:2612-2625

Jochum KP, Dingwell DB, Rocholl A, Stoll B and 32 others (2000) The preparation and preliminary characterisation of eight geological MPI-DING reference glasses for in-site microanalysis. Geostand Newslett 24:87-133

Kalish JM (1990) Use of otolith microchemistry to distinguish the progeny of sympatric anadromous and nonanadromous salmonids. Fish Bull 88:657-666

Kristensen TK (1980) Periodical growth rings in cephalopod statoliths. Dana 1:39-51

Kristensen TK (1984) Biology of the squid Gonatus fabricii (Lichtenstein, 1818) from West Greenland waters. Meddr Grønland Biosci 13:1-20

Lea DW, Shen GT, Boyle EA (1989) Coralline barium records temporal variability in equatorial Pacific upwelling. Nature 340:373-376

Lick R, Piatkowski U (1998) Cephalopod beaks from the stomach of a northern bottlenose whale (Hyperoodon ampullatus) stranded at Hiddensee, Baltic Sea. J Mar Biol Assoc UK 78:643-650

Lipinski MR (1979) Universal maturity scale for commercially important squids (Cephalopoda: Teuthoidea). ICNAF Res Doc 79/II/38:53-64

Lipinski MR, Przybylowicz WJ, Durholtz MD, MesjaszPrzybylowicz J (1997) Quantitative micro-PIXE mapping of squid statoliths. Nucl Instr Meth Phys Res B 130: $374-380$

Min GR, Edwards RL, Taylor FW, Recy J, Gallup CD, Beck JW (1995) Annual cycles of U/Ca in coral skeletons and U/Ca thermometry. Geochim Cosmochim Acta 59: 2025-2042

Mitsuguchi T, Matsumoto E, Abe O, Uchida T, Isdale PJ (1996) $\mathrm{Mg} / \mathrm{Ca}$ thermometry in coral skeletons. Science 274:961-963

Morris CC (1991) Statocyst fluid composition and its effects on calcium carbonate precipitation in the squid Alloteuthis subulata (Lamarck, 1798): towards a model for biomineralization. Bull Mar Sci 49:379-388

Nesis KN (1965) Distribution and feeding of young squids Gonatus fabricii in the Labrador Sea and the Norwegian Sea. Oceanology 5:102-108

Ohde S, Hossain MMM, Ozaki H, Masuzawa T (2003) Uranium in coral skeletons determined by epithermal neutron activation analysis. J Radioanal Nucl Chem 258:275-280

Pearce NJG, Perkins WT, Westgate JA, Gorton MP, Jackson SE, Neal CL, Chenery SP (1997) A compilation of new and published major and trace element data for NIST SRM 610 and NIST SRM 612 glass reference materials. Geostand Newsl 21:115-144

Piatkowski U, Wieland K (1993) The boreoatlantic squid Gonatus fabricii: distribution and size off West Greenland in summer 1989 and in summer and autumn 1990. Aquat Living Resour 6:109-114

Radtke RL (1983) Chemical and structural characteristics of statoliths from the short-finned squid Illex illecebrosus. Mar Biol 76:47-54

Rodhouse PGK, Robinson K, Gajdatsy SB, Daly HI, Ashmore, MJS (1994) Growth, age structure and environmental history in cephalopod Martialia hyadesi (Teuthoidea: Ommastrephidae) at the Antarctic Polar Frontal Zone and on the Patagonian Shelf Edge. Antarct Sci 6:259-268

Schlitzer R (2007) Ocean Data View (ODV). http://odv.awi.de

Shen GT, Dunbar RB (1995) Environmental controls on uranium in reef corals. Geochim Cosmochim Acta 59: 2009-2024 
Smith SV, Buddermeier RW, Redalje RC, Houck JE (1979) Strontium-calcium thermometry in coral skeletons. Science 204:404-407

Vander Putten E, Dehairs F, Keppens E, Baeyens W (2000) High resolution distribution of trace elements in the calcite shell layer of modern Mytilus edulis: Environmental and biological controls. Geochim Cosmochim Acta 64: 997-1011

Yatsu A, Mochioka N, Morishita K, Toh H (1998) Strontium/ Calcium ratios in statoliths of the neon flying squid Ommastrephes bartrami (Cephalopoda) in the North Pacific Ocean. Mar Biol 131:275-282

Zacherl DC, Manriquez PH, Paradis GD, Day RW, Castilla JC,

Editorial responsibility: Otto Kinne (Editor-in-Chief), Oldendorf/Luhe, Germany
Warner RR, Lea DW, Gaines SD (2003a) Trace elemental fingerprinting of gastropod statoliths to study larval dispersal trajectories. Mar Ecol Prog Ser 284:297-303

Zacherl DC, Paradis G, Lea DW (2003b) Barium and strontium uptake into larval protoconchs and statoliths of the marine neogastropod Kelletia kelletii. Geochim Cosmochim Acta 67:4091-4099

Zumholz K, Frandsen RP (2006) New information on the life history of cephalopods off west Greenland. Polar Biol 29: 169-178

Zumholz K, Hansteen TH, Klügel A, Piatkowski U (2006) Food effects on statolith composition of the common cuttlefish (Sepia officinalis). Mar Biol 150:237-244

Submitted: January 9, 2006; Accepted: August 17, 2006

Proofs received from author(s): March 1, 2007 